\title{
Chewable Bar Dosage Form
}

National Cancer Institute

\section{Source}

National Cancer Institute. Chewable Bar Dosage Form. NCI Thesaurus. Code C42892.

A bar designed to be chewed to release active and/or inert ing redient(s). 